\title{
THE DESTRUCTION OF LEGAL REASON: LESSONS FROM THE PAST
}

\begin{abstract}
The legal predicament of today in Europe and beyond takes the form of a devaluation of the meaning of legality, constitutionality and, of the rule of law. What we are dealing with is yet another crisis of both the tradition of the Rechtsstaat in continental setting and, more broadly, of liberal legality. While this disruption within the sphere of the law seems to mirror the reshuffling in established politics that took place over the last twenty years, it traces back to central jurisprudential questions that have made the substance of crucial debates during the interwar and have fashioned both the field of constitutional theory of the continent and our jurisprudential apparatus for approaching the nexus between law and politics.

In this article I argue that the apparent uchronia that the current status of the law opens in relation to past theoretical questions that were seeking to ground legality, is neither a simple byproduct of a Zeigeist oversaturated by appeals to procedural democracy or for returns to sovereign power, nor a mere regression to past juridico-political settings. It is a historical development that has been dormant for the past decades, yet has slowly undermined legal thought and praxis. Revisiting, as a matter of historical and jurisprudential inquiry, the context and the content of this original opposition between liberal legality and its enemy, is a way of understanding what constructs our own contemporary situation.
\end{abstract}

Keywords: authoritarianism, interwar, legal history, legal theory, liberal legality, rule of law.

\section{LAW, THEORY AND THE RISE OF AUTHORITARIANISM}

Eugène Ionesco's play Rhinoceros (Ionesco 1959) offers a convenient starting point for the reflection I intend to develop here. Wrote in 1959 and staged in the same year, the highly acclaimed play was often read - and this with the support of the author (Ionesco 1966, 277-278) - as an allegory of the rise of fascism. Set up in a small French village, it tells the story of a sudden contagion of rhinoceritis - a disease that strangely turns all the inhabitants save the main character into rhinoceros. Two recurring themes are of central importance for my argument: the transformation is doubled by an ominous thumping of marching rhinoceros, and all the characters - save from the main one - speak in clichés.

I argue that in many respects this is the position of the legal theoretical field today - that is, hesitating between giving way to the sound of rhinoceros and

* University of Nottingham, Faculty of Law and Social Sciences, School of Law, cosmin.cercel@nottingham.ac.uk 
finding an apparent solace in the performance of rituals, clichés and platitudes. Let us unpack this metaphor further with the help of Lacanian psychoanalysis. Whereas the thumping of the rhinoceros stands for a signal of the Real (Lacan 1974, 93; Žižek 2002), that is of what cannot be symbolised as such and therefore disrupts the symbolic order, the recurrent production of clichés is a form of the disque-ourcourant, ${ }^{1}$ the failure of the symbolic to ground itself (Lacan 1975, 35). These positions are supporting each other, and it is worth noting that in Ionesco's play it is those who are afflicted by rhinoceritis that use clichés, as if that would enable one to do away with the brutal presence of the animals. The legal theoretical field's reaction to the rise of authoritarianism seems somehow to follow the same line, being caught between a constant disavowal of the unbearable materiality of politics and an indistinct attempt at articulating a meaning of the current crisis. It is thus high time that we ask ourselves how are we in the field of law able to discern, let alone understand, the overtones of what lies outside of the law, at its borders and nonetheless structures it?

The question is how are we as critical lawyers in Central and Eastern Europe to address the present of looming catastrophes? While at the surface the situation appears to be desperate (Tacik 2019), the existing structures of the law are still there to offer some comfort by their seemingly timeless 'monumental' (Felman 2002, 203) existence. To be sure, there was during the last years a level of disruption forcing the venerable tenets of the law to disclose their structure and to ask fundamental questions related to the nature of our polities in the West and beyond. Even adepts of the doctrinal canon would be able to point to at least the technicalities of Miller cases, ${ }^{2}$ the limitations and special measures entailed by the state of emergency in France, ${ }^{3}$ President Trump's executive orders, ${ }^{4}$ and agree that they are something out of the ordinary in the humdrum life of law. Yet, in a sense, the situation is not serious. With very few exceptions, the liberal constitutions of the good old times are still in force with both their ideological content as well as symbolic value. Even the Treaty of Lisbon is unscathed positive law! Save for the content of electoral politics everything seems to be in its place, and, in a continuation of the Apollonian dream of the "end of history", there are still voices preaching the resilience of democratic institutions and law and their capacity of containing disaster. As Gábor Halmai writes, "liberalism is ... a constitutive precondition for democracy, which provides for the rule of law, checks and balances, and guaranteed fundamental rights" (Halmai 2019, 311).

Against this position I claim there should be little comfort in the very existence of the law as such with both its conceptual content and its intellectual

${ }^{1}$ For Lacan, the common discourse in which the subject is entangled, is turns in circle as a disk, in constant ignorance of the unconscious and the Real.

${ }^{2}$ Miller 1; Miller 2.

${ }^{3}$ Decree 1475/2015; Statute 1501/2015.

${ }^{4}$ Proclamation 9844/2019. 
history. Looked at from this perspective the situation is both serious and desperate. The conceptual body of law continue to entertain - and, as a consequence, is able to re-enact - a historical link with the anti-democratic projects of the past century. Even if explored and documented on various instances (Joerges, Ghaleigh 2003; Fraser 2005; Skinner 2015; Cercel 2017; Skinner 2019a), this nexus is obscured both by an ideological apparatus nested within the field of legal theory and by the continuous devaluation of legal thought.

Let us be more specific about the salient features of the status of law and legal thought today in order to understand the destitution befalling the legal enterprise. On one hand, what we are facing is of a struggle between the various discourses and grammars of addressing the on-going movements in the realm of social reality - be they of economical or political nature, while on the other hand we are witnessing an inner crisis of the jurisprudential enterprise. Viewed from the outside, this can be understood as a form of radical irritation (Luhmann 2004, 366-367), in which the law recedes at the pressure of politics and economics to the point of losing its internal coherence. Yet, within the spheres of law's self-representation, the legal orthodoxy continues its squabbles over definitional strategies and conceptual clarifications seemingly divining the sphere of legality (Harel 2014, 107-129) and continuing to instil the faith in the law (Goodrich 1983, 255; Mańko 2013).

We are living thus at least two quite distinct dynamics, which both expose and found our legal present. The fact that legality, understood here as a both jurisprudential and philosophical category articulating what counts as lawful, is in crisis is not something entirely new. The neoliberal turn in the 1970s (Dardot, Laval 2013, 16-17) and the reconstruction of the state along the new lines in political theory and practice have left a visible trace on the ways of approaching law as a form of social regulation. The old paradigms of a pyramidal production of legislation with the state in its centre have left their place to multi-layered, horizontal (Ost, Van de Kerchove 2002), even rhizomatic (PhilippopoulosMihalopoulos 2016) models of law in society. Legal pluralism, law-in-context, the rise of sociological, empirical-evidenced, or policy-oriented analysis of law have seemingly sapped even more the tenets of the jurisprudential enterprise and have significantly undermined its pretence at constructing an overarching theory of law. Despite these movements, or perhaps in strong connection to them, the legal canon survived and grew stronger. The position of the lawyer nowadays is thus that one of typical 'fetishist disavowal' (Žižek 1993, 88 ; Žižek 2001, 89). It takes a form that can easily be articulated along the following lines: "I know very well that the law is not grounded in its own self-reference, that the legal field is not easy to delineate, yet as a matter of legal practice I act as if it is".

At the antipodes, the rebellion of the CLS with its insistence on law-as-politics (Unger 1986) surrendered its critical thrust long time ago. The revolution was betrayed or simply quelled (Fraser 1987). For their part, the various attempts of 
the critical field in displacing both hierarchies and the 'sublime object' (Žižek 2008, 12-14) of the law are constantly losing ground. The critical legal multitude seems to be caught up in a theoretical war of attrition against the established canon, one which lasts for more than three decades now and which witnessed very limited progress on any front. Its relentless opposition to the mainstream spheres of ideological production, has yet left unscathed "that which is "rotten" in the law' (Derrida 1991, 95). Positing itself on the side of the non-knowledge and professing an uneasy attack on the knowledge of the Master (Lacan, 1991 [1970], 159) the critical field runs the serious risk to turn into a continuous celebration of transgression, which by its very structure keeps us closer to the established powers of the legal field. As Joan Copjec aptly noted, 'laws are made to be broken, prohibitions to be transgressed, but through its very violability the law binds us closer to it' (Copjec 1991, 29).

To put it simply, we have reached a point where not only the object of the legal enterprise had become obscure in a determinant manner, but it appears that the operation of the law itself attained a level of obscurity that makes it impenetrable to theorisation (Douzinas 2014, 190). In the light of the unfolding catastrophe, law simply is. If this theoretical cul de sac would be limited to the confines of the ivory towers of jurisprudence, perhaps the situation would not be serious. However under the strain of the present, we are compelled to rethink both the tenets of our theoretical standing as well as the nature of our engagement, be it simply because legal theory is still, rightly or wrongly, the site where our most basic tenets of articulating the meaning of law are forged.

Before moving forward on this path it would be useful to take further the measure of the changes that have befallen the existing body of law in our polities during the last decades in order to understand the structural imbalance at the core of legality. At a first glance, such changes seem to mirror the inconsistencies in legal thought, albeit in a rather cruder manner, that signals law's inscription in the contemporary capitalist flux (Hunt 1985, 15). As such, at the level of private law, we have been witnessing a shift from the imagined autonomous subject entering contracts out of his (most often than her) own volition, to a new and somewhat obscure stand, that of the consumer which is protected and enabled by the law in this economic position (Mańko 2015, 42-43). In criminal law there is an ongoing shift from traditional categories of crime based on the both act and intent towards new forms broadening the scope of notions such as intent and bordering dangerously to status as to give way to the prevention of criminal conduct (Asp 2013; Dyzenhaus 2013). Fundamental rights and criminal legislation have always had an uneasy interaction, but the emergence of anti-terrorist legislation from the 1970s onwards had made it all the more ambiguous (Dyzenhaus 2013; Sajó, Uitz 2017, 440-444; Skinner 2019b; Skinner 2011).

For its part, public law principles are not only encroached by private/ public mixed concepts (Hesselink 2002), but also the very position of the state 
becomes obscured under these arrangements. Last, and certainly not least, the sphere of constitutional law emerged as both the most sensitive to the recent authoritarian onslaught and embarked on an unprecedented dialogue with political science in a seemingly failed attempt to make sense of the rise of populism. Yet, symptomatically, before lending itself to the wild goose chase of 'populism' (Müller 2016, 19-20) constitutional law was precisely the laboratory where classical concepts of sovereignty, citizenship and belonging were recast in a global and transnational mould (Weiler, Wind 2003; Rosenfeld 2010).

Furthermore, the traditional early modern systematisation of law through codes, has shifted to a myriad of legislations of various forms and forces which are both theoretically and practically hard to subsume to a set of principles and rules. In a Foucauldian turn, the decapitated sovereign body returned as manifold continual haunting, where the law seemingly dissolved in a sea of regulations, and norms have replaced juridical artefacts. As it has been noted at the zenith of this historical trajectory, 'law is no longer valid as an expression of a general will or common interest. Rather, it is valid by virtue of its normative quality' (Ewald 1990, 155). Reality is in flux, and a continual state of exception has insinuated itself as a new rule (Agamben 2005), laying down the new laws of a dystopian legal universe of texts without normative content and with norms without texts.

\section{A GENEALOGY OF THE PRESENT}

In Central and Eastern Europe, one would have expected lawyers to have a more sensitive ear to the sound of rhinoceros, if the protection of the normative liberal promise was indeed on their agenda. Yet, from the very beginning of the post-communist transformation, the intermingling between law and politics was worrying (Teitel 2002, 13-19) and startling in so many respects that it should have at least raised serious doubts about what the upholding of legality was able to mean in the forthcoming future (Cercel 2017, 2-5). For instance, the privileged frame of reading the communist legacy under the seal of lawlessness and a constant conflation of the communist experience with other authoritarianisms under a lax interpretation of totalitarianism (Arendt 1985 [1951]; Losurdo 2015 [1996], 26; Traverso 2019, 181-182), was at least indicative of the political roots of the emerging constitutionalism in Central and Eastern Europe. Under the waves of enthusiasm fuelled by the 'sacrificial violence' (Girard 1977) of the tyrannical past, both theoretical and memorial concerns over the process of dealing with the past were easily side-lined. Indeed, not only the legal theoretical antinomies highlighted by attempts of retrospective and restorative justice (Hart 1958; Fuller 1958; Fraser 2011) were left outside the scope of public and academic debates, but also the very post-war consensus over right-wing authoritarian past was put into question (Stone 2014). This process was celebrated as nothing short than a return 
to normality (Krygier 1990, 635). As it has been written, in the wake of the fall of the Berlin wall: '[n]ormality has been absent from east central Europe for a very long time. One of its elements is the role played by law' (Krygier 1990, 638).

As it was unravelled by further developments in transitional constitutionalism, normality was nothing short than a particular arrangement between economic liberal values and rule of law, that is 'liberal democratic politics, capitalist economics, both undergirded by the rule of law' (Czarnota, Krygier, Sadurski $2005,1)$. And yes, normality was what we called the neoliberal onslaught on both social rights and traditional forms of legality (Sadurski 2005, 9). One could thus easily speculate to each extent behind the pledges to uphold a particular version of legality, schmittian echoes were to be heard, insofar as 'for a legal order to make sense, a normal situation must exist and he is sovereign who decides whether this normal situation actually exists' (Schmitt 1985 [1922], 13).

$\mathrm{Be}$ it as it may, thrown into the world of freedom and capital accumulation, being on the frontline of the ideological offensive that conflated economical, moral and legal categories (Cercel 2017, 203-205), our polities have soon gave way to the latent ex-timate ${ }^{5}$ Lacan 1966, 524) of the (neo)liberal order. The law was there to comfort this change, be it by the very processes of transitional justice, constitutional reform, or by the reconstruction of its own social guarantees. It was also there all the way, even through its absence and through arbitrary application, by complacently effacing or suspending itself through the constant 'management of illegalisms' (Foucault 1975, 98-106) or by strategically inscribing itself as force in protecting the very economical basis of the new legal and constitutional arrangements. And so was legal theory, in its decrepit gowns of respectability moving between a mimicry of a science of norms and an apology of the established order. Law and legal thought continued their existence while a social catastrophe was unfolding.

In the case of a number of Central and Eastern European countries the writing was on the wall from the times of the secret torture sites ${ }^{6}$ to those of the revisions of the labour law legislation limiting collective bargaining (Trif 2013, 231-234; Guga 2014, 152-155). More specifically, in Romania, the authoritarian slide became even more startling from the passing of austerity measures with disregard to the constitutional process ${ }^{7}$ to the repression of anti-austerity protests (Cercel 2014, 142-143), marking the long decade of triumphant neoliberalism (Poenaru, Rogozanu, 2014; Damșa 2016) and heralding the entry of the region fully within the sphere of struggles that swept the world in the years of dreaming dangerously (Žižek 2012), from Madison to Athens (Cistelecan 2015).

${ }^{5}$ For Lacan an ex-timate, defines what is more real within the subject than the subject itself, and which necessarily captures to the subject's relation to its other.

${ }^{6}$ Al Nashiri v. Poland, ECtHR, 24 July 2014; Al Nashiri v Romania, ECtHR, 31 May 2018.

${ }^{7}$ Romanian Constitutional Court, Advisory Opinon No. 456, 12 July 2012. 
Surprising as it might seem at a first glance, the turn towards an ideological position brandishing the flags of national identity and sovereignty, is yet part of the same historical trajectory that started with the so-called return to normality, and has insidiously taken place under the shadow of the same politico-legal arrangements that celebrated under the label of rule of law. Even more, let alone its national overtones, there is a clear transnational dimension to this affirmation of anti-liberalism, the otherwise obverse of the failed emancipatory potential diluted in the early 2010s.

The fact that the liberal paradigm gives way to new politico-legal arrangements cannot be easily dismissed as simply a passing scare or a some fleeting hick-up within the unstoppable progress towards a global democratic governance. At the core of this process there is a tension over the meaning of legality that goes beyond the mere posited ascriptions of this term within local constitutional contexts be they Poland, Hungary, or for that matter, the United Kingdom. Rather, we are witnessing a trend towards a reconstruction of the basic features of what law signifies in its relation to politics and has largely signified since the fall of fascism in the West and the putative return to liberal democracy in Eastern Europe. This turn still takes the form of a minute accumulation of social, political and technical legal pressure that reconstruct both the 'high' and the 'low' of our cultural existence. The authoritarian turn appears thus as a series of strategic and overtly symbolic changes within the body of the law or state practice (Scheppele 2018, 550-551; Sadurski 2019, 58-95), while at times is made up of silent and unnoticeable changes constructing the new normality (Varol 2015). This trend takes the form of laws of memory aiming to rewrite positively the past according to new protocols in imagining the history of the Nation (Belavusau, Gliszczyńska-Grabias 2017, 10-14) the call for an ideological purity through law (Könczöl 2017, 253-260), just as there is the constant movement of reframing subjectivities by the uses of criminal law geared towards protection of borders and the rise of the 'preventive state' (Sajó, Uitz, 440-444).

Yet, this crisis of legality, that is a critical reconstruction of the tenets of what is to count as legal, is something that escapes to a strictly legal theorisation and for that matter to a jurisprudential approach. Concepts such as 'populist constitutionalism' (Landau 2018) 'autocratic legalism' (Scheppele 2018) and 'stealth authoritarianism' (Varol 2015) have become the new symbolic veil that covers a present marked by conflict, tensions, struggle and repression. What was left unchallenged was, unsurprisingly, the place and function of legal normativity within this very dynamic of law's self-erasure. In order to be able to understand its deeper significance, one needs to move away from the "now" of the law and seek in both its conceptual structure and intellectual history that which renders it permeable to authoritarian uses and connivant to authoritarian projects.

Today the blind machinery of the law (Schütz 2000, 109) has found a no less sightless companion to guide its steps in the time of catastrophes. If we are 
to examine this destitution of legality, there are indeed parallels to be drawn with other times of crisis. However, there is more than a formal similarity that can be inferred from the on-going capitalist crisis and the steps towards the breakdown of democracy specific to the interwar. That is because legal discourse has the peculiarity of both registering, archiving (Mawani 2012) and re-enacting its own history. Furthermore, at the core of this process of erosion of legality, what is at stake is the very undoing of the central tenet of the transnational postwar ideology - the "rule of law" - which was itself constructed at the intersection of crisis, revolutions and social strife.

\section{A JURISPRUDENCE OF CRISIS: LESSONS FROM THE PAST}

Understood in its own terms, law is timeless and at the same time historical. Through its unfolding, the ongoing crisis reactivates the formal and material patterns of law's destitution that have been latent during the past decades. That is because, as Anton Schütz noted following Agamben, the operation of the law is 'essentially exceptional, and under the rule of law as the rule of the delayed exception, as the rule of the ever saved, ever not yet performed (but yet threatening) performance or decision' (Schütz 2000, 117). It is thus necessary to resist to the temptation of opposing a lawful and law-full liberal tradition to a lawless, barbarian attack on legality. What we need is indeed to be able to articulate and revisit law's inner tensions turning it into 'a monument of its own destitution' (Schütz 2008, 127). Otherwise said, we should be able to map and document is law's inner cut that is constitutive of its own history within the liberal tradition.

What I propose as a possible answer to the current debasement of legality, is a radical revision the key opposition heralded in the 1930s by the Schmittian attack on Kelsenian pure theory of law. While indeed a remarkable literature documents the political, historical, and jurisprudential grounds of the debate (Arvidsson, Brännström, Minkkinen 2016; McCormick 1997; Scheuerman 1999) focusing on either the constitutional aspects (Vinx 2015), the socio-political dimensions (Simard 2009) or the lessons to be drawn from the breakdown of the Weimar republic (Jacobson, Schlink 2000) the focus is still too narrow. What we lack, is a broader framework of understanding the particular fracture between liberal legality and right-wing authoritarianism beyond the borders of the German legal science, and as a symptom of a political reshuffling in times of crises. In other words, we need to understand in their proper frames and grammars the reasoning that have shaped the fall of Europe in the shadow of authoritarianism during the interwar.

This is not purely a matter of historiography, but essentially a way of capturing the functioning of liberal legal thought in times of crisis. That is 
because the intellectual weight of this debate is far from being exhausted, as it is emblematic for the tensions inherent to liberal legality from its advent to its zenith. Moreover, there is a formal historical parallelism between our authoritarian turn in Central and Eastern Europe and the troubled times of the interwar period that can be warranted beyond the mere contingent rhetorical appeals to the Nation, sovereignty and antisemitic innuendos that make the matter of our politico-legal present predicament.

To put it simply, the crisis of legality during the interwar took place in a constitutional and historical context that from the standpoint of legal history was not far removed from our experience in Central and Eastern Europe during the last decade, but entertained historical, if not causal, ties with our present. True, both the Weimar Republic and the First Austrian Republic emerged at the end of a catastrophic conflict that was unique in European history, which by its very existence has completely altered the politico-legal landscape as well as the very subjectivity of individuals. As an astute observer of the interwar such as Walter Benjamin noted, 'never has experience been contradicted more thoroughly than strategic experience by tactical warfare, economic experience by inflation, bodily experience by mechanical warfare, moral experience by those in power' (Benjamin 1969 [1936], 84).

For its part, the Central and Eastern European post-communist constitutionalism is the product of a different upheaval, that is the fall of statesteered projects of building communism. While the Weimar, and for that matter, Versailles and the numerous other states born or reshaped in its wake, rose on the ashes of the Empires, Central and Eastern European liberal legality was built on a failure of socialism. Granted, both regimes of legality appear at the end of a radical disruption, that is at the end of the Great War and Cold War era, but the term war can only function as a misnomer here, as in 1989 there was no peace settlement as such being sanctioned or recognised as a matter of law (Barbu 1998, 267-271), while at the same time there was no legal mechanism overseeing or guiding the conditions of peace. To be sure 1989 was not 1919. After the fall of the Berlin wall there was no peace treaty, and except for Romania and USSR, the regime change was mainly negotiated.

At the same time, the revolutionary turmoil was by and large that of a "velvet Revolution". Yet, this does not necessarily mean that there were no victors and winners (Barbu 1998, 268), or radical changes disturbing social structures and the lives of people. As it has been noted: "no country that was affected by the Great Depression of 1933 suffered so many effects as the ex-communist countries at the beginning of the transition. Even if initially it seemed to be only a metaphor, it became manifest that these countries have lost, after all, a war' (Poenaru 2017, 8). Even more, not completely unrelated to the fall of communism, territorial changes ensued, giving rise to overt conflicts that still continue up to this day. Some of the emerging states were indeed simply re-casted within their old borders of 
1918-1919 as in the case of the Baltic States and to some extent Ukraine, Georgia or Armenia, while frontlines have emerged along the old pre-World War I and World War II borders in former Yugoslavia. Of course, there is very little which could warrant a strict historical similarity, especially if we are approaching this context from the standpoint of the content of established politics. As a matter of fact, one of the main forces that was present at the end of World War 1 was completely missing both as a political party and as a theoretical movement, namely revolutionary socialism. One cannot overemphasize the extent to which this parallelism can be read only at a purely formal level, as a return of a legal configuration mirroring times of crisis.

However, what indeed can be regarded to be similar in the antecedents of this breakdown of democracy is the peculiar way of clinging to a particular version of liberal legality as a central feature of the polities that would be able to do away with what was often termed as the difficult transition from dictatorship to democracy. As it was thought, law was the discourse able to provide the neutral medium for grievances and conflict (Habermas 1993; Habermas, Rehg 2001, 770). In its apparent position of an 'absolute third' (Ricœur 1995, 11-13), it purportedly embodied the very symbolic frame of a society from which both class and political conflict were expunged. In the words of Kelsen, still echoing in today's politicolegal theory, "it is [...] a procedure, a specific method of creating and applying the social order constituting the community, which is the criterion of that political system which is properly called democracy" (Kelsen 1955, 1). The proliferation of autonomous institutions, the continuous constitutional reforms and debates arising from a constant search of clarity and predictability that have marked our polities up to this day, as well as the ideological attachment to the belief in law as foundational for polities are reminiscent of an unavowed, and for that matter, an unarticulated version of legal formalism that ultimately turns around the conundrum of liberal legality in times of crisis. During the interwar years, this position was emphatically epitomised in both liberal and reactionary concepts. As such, one should recall the double meaning of the constitution revealed by Carl Schmitt. As he wrote,

"constitution" can describe the state itself [...] an individual concrete state as political unity [...]. In this instance it means the complete condition of political unity and order. Yet, "constitution" can also mean a closed system of norms and [...] designate a unity [...] a reflective, ideal one (Schmitt 2008 [1928], 59).

For Kelsen, insofar as the state is 'a social structure' analysable as "a system of human behaviour" based on coercion, it can be properly understood in terms of law: "the state [...] is a legal system" (Kelsen 1992 [1934], 100). Beyond the substantial oppositions of these positions, that is between a concrete legal order and the state's foundation on abstract normativity, we can seize the specific primacy of the question of legality during the interwar years. Whereas, the affirmation of 
formal legality as a ground for the state had at least two opposing meanings, it aimed at doing away with the materiality of struggles and politics. Indeed, there is an amphiboly in this position, insofar the state and constitutionalism are one hand construed as essentially forms of political compromise (Schmitt 2008 [1928], 8288) aimed at keeping at bay social strife and on the other hand, they are conceived as an embodiment of reason that can be reduced as a set of rules related through validity (Kelsen 1992 [1934], 99).

Yet, both positions do aim to give grounding to the state by excluding either the absolute enmity of civil war or the arbitrariness of irrational power struggles. In this sense, the state was either saved as an embodiment of rationality, or as a force beyond individual significance. This ambiguity goes beyond the singular case of Weimar Germany. In whole Europe, dealing with either the threat of revolutionary communism, class struggle and later with the rise of fascism, law would be split between a formal subsistence of substantive political, civil and individual rights and a series of exceptional measures effectively limiting the emancipatory potential of rights. This would take either the radical forms of martial law, state of siege - or state of exception, that is on the formal and effective suspension of the constitutional process, or more diffuse forms of criminal and administrative repression minutely sapping the scope and meaning of constitutional provisions. In these sense, liberal legality, in the context of the 'sense-making crisis' (Platt $1998,208)$ emerges as nothing else that a system at war with itself, in which the ultimate goal was a struggle over the meaning of legality.

If we are to approach the present crisis in Central and Eastern Europe, we need then to be able to return to the original meaning of the liberal belief in legality that constituted the legal matter of the post-communist transformation. This dispositive of legality was indeed not only the prevailing language of transitional constitutionalism and transitional justice, but also that of the prevalent constitutional theory, spilling later into the ideology of institutional and political actors and even going beyond the formal borders of the polities. In short, it was the politico-legal theory of the lawyers and officials in Central and Eastern Europe determined to break with the past and to pave the way to a new form of constitutional patriotism (Sulikowski 2016, 24-27).

Within this project, democracy, the rule of law and market economy are conflated under one and the same theoretical framework that, rightly or wrongly, still bears the name of liberalism. This confusion should not be taken only as a fleeting error, rather it is part of the very apparatus of neoliberal transformation that linked together the markets as producers and bearers of social truth, under the ideology of monetarism (Eyal, Szelenyi, Townsley 2001, 87-91) and the "civil society", with its seemingly generous promises of a stable legality able to endorse social change with its specific legitimacy.

It is indeed this unholy alliance between the intellectual elite and the markets that is perhaps at the core of the vagaries of the post-communist transformation 
(Eyal, Szelenyi, Townsley 2001, 91-96). With the consensus that markets are the depositary of an ultimate social meaning and the position of the free individuals responsible for their actions, constitutional theory and what was left of the jurisprudential enterprise, were bound to turn into a search for ways of limiting state discretion as to offer a constant predictability and freedom of action for the economic actors. The arbitrary inherent in the functioning of the traditional administrative machinery was to be externalised to the economic sphere where they were deemed to disappear as it was unquestionable that real rational mechanisms of the economy ultimately drive markets.

\section{CONCLUSION}

Following this thread, what we are witnessing at this very moment is the last series of events signalling a decoupling of the ideological connection between free markets and the so-called liberal freedoms in the sense that the former could easily operate without the latter. Indeed, this connection was anything but necessary and it should be understood in its proper historical context that is of a coalescence linking the interests of the capital to the liberal form of democracy. This is the reason for which a particular view of law and democracy has been revived as a mechanism instrumental to the operation of the transformation, while at the same time being elevated to the central ideological position: the ultimate truth about law and state.

It should not be a surprise then that when the presumed rationality inherent in the markets failed, the ideological justification supporting an already fragile arrangement started to show its cracks and reactivate the very coordinates that founded modern legality. The present breakdown of democracy in Central and Eastern Europe is thus the drama of a law left to its own devices that can no longer sustain the ideological pledge of the rationality of the markets and seeks to find its grounding. In this sense, the re-emergence of sovereign, identarian and nationalist tropes is not necessarily a regression to a pre-juridical or premodern state, a lawless barbarian onslaught, but a reconstruction of law within the boundaries of what was already present in the structure of liberal legality itself.

If indeed it is the specific legal form of fetishist disavowal that is at the core of the present destruction of legal reason by keeping lawyers' and legal theorists' eyes closed to what supports legality, the task that lies before us is not a simple one. It is not to merely refocus the legal mind as to grasp the disruptions within the symbolic order, rather, it is to point out to which extent the symbolic coordinates of liberal legality were and still are fluid, and they offer very little, if any, comfort in front of the authoritarian assertion of power. To put it simply, the task is to show the contingency of the legal form, its historical inscription in a history, that is as any history one of class struggle. In this sense, engaging in critical socio-legal histories 
of the law within our polities, bearing the very marks of this struggle is crucial in order to expose law's connivance with authority and its mythical foundations. The historical trajectory of law in Central and Eastern Europe is itself a living embodiment of this conundrum. Yet, while this task is important and necessary, we should also be able to move beyond the frames of the legal form itself and map the nexus that ties legality and the structures of economy and politics.

Research for this paper was undertaken within the project Heads of State (Princes, Kings and Presidents) and the Authoritarian Dynamic of Political Power in Romanian Constitutional History, funded by the Romanian Research Funding Agency (UEFISCDI), PN-III-P4-ID-PCE-2016-0013.

\section{BIBLIOGRAPHY}

\section{References}

Agamben, Giorgio. 2005. State of Exception. Chicago: University of Chicago Press.

Arendt, Hannah. 1985 [1951]. Origins of Totalitarianism. New York: Harvest Books \& Harcourt.

Arvidsson, Matilda. Leila Brännström. Panu Minkkinen. 2016. The Contemporary Relevance of Carl Schmitt: Law, Politics, Theology. London: Routledge.

Asp, Petter. 2013. "Preventionism and Criminalization of Nonconsummate Offences". In Prevention and the Limits of Criminal Law. 23-46. Edited by Andrew Ashworth, Lucia Zedner, Patrick Tomlin. Oxford: Oxford University Press.

Barbu, Daniel. 1998. Republica absentă. Bucharest: Nemira.

Belavusau, Uladzislau. Aleksandra Gliszczyńska-Grabias. 2017. "Introduction: Memory Laws: Mapping a New Subject in Comparative Law and Transitional Justice". In Law and Memory: Towards Legal Governance of History. 1-26. Edited by Uladzislau Belavusau, Aleksandra Gliszczyńska-Grabias. Cambridge: Cambridge University Press.

Benjamin, Walter. 1969 [1936]. "The Storyteller”. In Illuminations. 83-110. Edited by Hannah Arendt. New York: Schocken Books.

Cercel, Cosmin. 2017. Towards a Jurisprudence of State Communism. London: Routledge.

Cistelecan, Alex. 2015. "From Region to Culture, from Culture to Class". Journal of Contemporary Central and Eastern Europe 25: 45-60.

Copjec, Joan. 1991. "Vampires, Breast-Feeding, and Anxiety". October 58: 22-45.

Czarnota, Adam. Martin Krygier. Wojciech Sadurski. 2005. "Introduction". In Rethinking the Rule of Law after Communism. 1-8. Edited by Adam Czarnota, Martin Krygier, Wojciech Sadurski. Budapest: Central European University Press.

Damşa, Liviu. 2016. The Transformation of Property Regimes and Transitional Justice in Central Eastern Europe. Heidelberg: Springer.

Dardot, Pierre. Christian Laval. 2013. The New Way of the World: On Neoliberal Society. London: Verso.

Derrida, Jacques. 1994. Force de loi. Paris: Galilée.

Douzinas, Costas. 2014. "A Short History of the British Critical Legal Conference or, the Responsibility of the Critic". Law and Critique 25: 187-198.

Dyzenhaus, David. 2013. "Preventive Justice and the Rule of Law Project". In Prevention and the Limits of Criminal Law. 91-114. Edited by Andrew Ashworth, Lucia Zedner, Patrick Tomlin. Oxford: Oxford University Press. 
Ewald, François. 1990. "Norms, Discipline and the Law". Representations 30: 138-161.

Eyal, Gill. Ivan Szelenyi. Eleanor Townsley. 2001. Making Capitalism Without Capitalists. The New Ruling Elites in Eastern Europe. London: Verso.

Felman, Shoshana. 2002. The Juridical Unconscious. Trials and Traumas in the Twentieth Century. Cambridge, MA: Harvard University Press.

Foucault, Michel. 1975. Surveiller et punir. Paris: Gallimard.

Fraser, David. 1987. "The Day The Music Died. The Civil Law Tradition from a Critical Legal Studies Perspective". Loyola Law Review 32: 861-880.

Fraser, David. 2005. Law after Auschwitz: Towards a Jurisprudence of the Holocaust. Durham, NC: Carolina Academic Press.

Fraser, David. 2011. "Shadows of Law, Shadows of Shoah: Towards a Legal Theory of the Nazi Killing Machine”. Oxford Journal of Legal Studies 32: 401-419.

Fuller, Lon Luvois. 1958. "Positivism and Fidelity to Law - A Reply to Professor Hart". Harvard Law Review 71: 630-672.

Girard, René. 1977. "Violence and Representation in the Mythical Text". Comparative Literature 92: 922-944.

Goodrich, Peter. 1983. "The Rise of Legal Formalism; or the Defenses of Legal Faith". Legal Studies 3: 248-266.

Guga, Ștefan. 2014. "Criza ca oportunitate: schimbarea legislației muncii și înfrângerea mișcării sindicale”. In Epoca Traian Băsescu: România între 2004 și 2014. 103-116. Edited by Florin Poenaru, Costi Rogozanu. Bucharest: Tact.

Habermas, Jürgen. 1993. Moral Consciousness and Communicative Action, Cambridge, MA: MIT University Press.

Habermas, Jürgen. William Rehg. 2001. "Constitutional Democracy: A Paradoxical Union of Contradictory Principles”. Political Philosophy 29: 766-781.

Halmai, Gábor. 2019. "Populism, Authoritarianism and Constitutionalism". German Law Journal 20: 296-313.

Harel, Alon. 2014. Why Law Matters. Oxford: Oxford University Press.

Hart, Herbert L. A. 1958. "Positivism and the Separation of Law and Morals". Harvard Law Review 71: 593-629.

Hesselink, Martijn W. 2002. "The New European Legal Culture". In The New European Private Law. 11-75. The Hague: Kluwer Law International.

Hunt, Alan. 1985. "The Ideology of Law: Advances and Problems in Recent Applications of the Concept of Ideology to the Analysis of Law". Law and Society Review 19: 11-37.

Ionesco, Eugène. 1959. Rhinocéros: pièce en trois actes et quatre tableaux. Paris: Gallimard.

Ionesco, Eugène. 1966. Notes et contre-notes. Paris: Gallimard.

Jacobson, Arthur J. Bernard Schlink. Eds. 2000. Weimar - a Jurisprudence of Crisis. Berkeley: University of California Press.

Joerges, Christian. Navraj Singh Ghaleigh. Eds. 2003. Darker Legacies of Law in Europe. Oxford: Hart Publishing.

Kelsen, Hans. 1955. "Foundations of Democracy". Ethics 66: 1-101.

Kelsen, Hans. 1992 [1934]. Introduction to the Problems of Legal Theory. Oxford: Oxford University Press.

Könczöl, Miklós. 2017. "Dealing with the Past in and around the Fundamental Law of Hungary". In Law and Memory: Towards Legal Governance of History. 246-262. Edited by Uladzislau Belavusau, Aleksandra Gliszczyńska-Grabias. Cambridge: Cambridge University Press.

Krygier, Martin. 1990. "Marxism and the Rule of Law: Reflections After the Collapse of Communism". Law and Social Inquiry 15: 633-663. 
Lacan, Jacques. 1966. "L'instance de la lettre dans l'inconscient ou la raison depuis Freud". In Écrits. Vol. 1. 493-528. Paris: Le Seuil.

Lacan, Jacques. 1974. "Le séminaire. Livre XXII. RSI. La scéance du 17 décembre 1974”. Ornicar? 2: 87-97.

Lacan, Jacques. 1975. Le séminaire: livre XX: Encore. Paris: Le Seuil.

Lacan, Jacques. 1991 [1970]. Le séminaire: livre XVII: L'envers de la psychanalyse. Paris: Le Seuil.

Landau, David. 2018. "Populist Constitutionalism". Chicago Law Review 85: 521-544.

Losurdo, Domenico. 2015 [1996]. War and Revolution: Rethinking the Twentieth Century. London: Verso.

Luhmann, Niklas. 2004. Law as a Social System. Oxford: Oxford University Press.

Mangabeira Unger, Roberto. 1986. The Critical Legal Studies Movement. Cambridge, MA: Harvard University Press.

Mańko, Rafał. 2013. "Weeds in the Garden of Justice. The Survival of Hyperpositivism in Polish Legal Culture as a Symptom/Sinthome". Polemos: Journal of Law, Literature and Culture 7(2): 207-233.

Mańko, Rafał. 2015. "Reality Is For Those Who Cannot Sustain the Dream: Fantasies of Selfhood in Legal Texts". Wroclaw Review of Law, Administration and Economics 5(1): 24-47.

McCormick, John P. 1997. Carl Schmitt's Critique of Liberalism. Cambridge: Cambridge University Press.

Müller, Jan-Werner. 2016. What Is Populism? Philadelphia: University of Pennsylvania Press.

Ost, François. Michel Van de Kerchove. 2002. De la pyramide au réseau? Bruxelles: Publications des Facultés Universitaires Saint-Louis.

Philippopoulos-Mihalopoulos, Andreas. 2016. "Flesh of the Law: Material Metaphors". Journal of Law and Society 43: 45-65.

Platt, Gerald M. 1998. "An Alternative Theory”. In International Fascism. 204-215. Edited by Roger Griffin. London: Arnold.

Poenaru, Florin. 2017. Locuri Comune: clasă, anticomunism, stânga. Bucharest: Tact.

Poenaru, Florin. Costi Rogozanu. 2014. Epoca Traian Băsescu: România între 2004 și 2014. Bucharest: Tact.

Ricœur, Paul. 1995. Le juste. Paris: Esprit.

Rosenfeld, Michel. 2010. The Identity of the Constitutional Subject: Selfhood, Citizenship, Culture, and Community. London: Routledge.

Sadurski, Wojciech. 2005. "Transitional Constitutionalism: Simplistic and Fancy Theories". In Rethinking the Rule of Law after Communism. 9-27. Edited by Adam Czarnota, Martin Krygier, Wojciech Sadurski. Budapest: Central European University Press.

Sadurski, Wojciech. 2019. Poland's Constitutional Breakdown. Oxford: Oxford University Press.

Sajó, András. Renáta Uitz. 2017. The Constitution of Freedom: An Introduction to Legal Constitutionalism. Oxford: Oxford University Press.

Scheppele, Kim Lane. 2018. “Autocratic Legalism”. University of Chicago Law Review 85: 545583.

Scheuerman, William E. 1999. Carl Schmitt: The End of Law. New York: Rowmann and Littlefield.

Schmitt, Carl. 1985 [1922]. Political Theology. Cambridge, MA: MIT Press.

Schmitt, Carl. 2008 [1928]. Constitutional Theory. Durham: Duke University Press.

Schütz, Anton. 2000. "Thinking the Law With and Against Luhmann, Legendre, Agamben". Law and Critique 11: 107-136.

Schütz, Anton. 2008. "The Fading Memory of Homo non Sacer". In The Work of Giorgio Agamben. Law, Literature, Life. 114-131. Edited by Justin Clemens, Nicholas Heron, Alex Murray. Edinburgh: Edinburgh University Press. 
Skinner, Stephen. 2011. "The Right to Life, Democracy and State Responsibility in 'Urban Guerilla' Conflict: the European Court of Human Rights Grand Chamber Judgment in Giuliani and Gaggio v. Italy". Human Rights Law Review 11: 567-577.

Skinner, Stephen. Ed. 2015. Fascism and Criminal Law: History, Theory, Continuity. Oxford: Hart Publishing.

Skinner, Stephen. Ed. 2019a. Ideology and Criminal Law: Fascist, National Socialist and Authoritarian Regimes. Oxford: Hart Publishing.

Skinner, Stephen. 2019b. Lethal Force, the Right to Life and the ECHR: Narratives of Death and Democracy. Oxford: Hart Publishing.

Stone, Dan. 2014. Goodbye to All That: A History of Europe since 1945. Oxford: Oxford University Press.

Sulikowski, Adam. 2016. "Government of Judges and Neoliberal Ideology: The Polish Case". In Law and Critique in Central and Eastern Europe. 16-31. Edited by Rafał Mańko, Cosmin Cercel, Adam Sulikowski. Oxford: Counterpress.

Tacik, Przemysław. 2019. "A New Popular Front, or, on the Role of Critical Jurisprudence under Neo-Authoritarianism in Central-Eastern Europe". Acta Universitatis Lodziensis. Folia Iuridica 89.

Teitel, Ruti. 2002. Transitional Justice. Oxford: Oxford University Press.

Traverso, Enzo. 2019. The New Faces of Fascism. London: Verso.

Trif, Aurora. 2013. "Romania: collective bargaining institutions under attack". Transfer: European Review of Labour Research 19(2): 227-237.

Varol, Ozan O. 2015. "Stealth Authoritarianism". Iowa Law Review 100: 1673-1742.

Vinx, Lars. 2015. The Guardian of the Constitution: Hans Kelsen and Carl Schmitt on the Limits of Constitutional Law. Cambridge: Cambridge University Press.

Weiler, Joseph H. H., Marlene Wind. 2003. European Constitutionalism Beyond the State. Cambridge: Cambridge University Press.

Žižek, Slavoj. 1993. Tarrying with the Negative: Kant, Hegel and the Critique of Ideology. Durham: Duke University Press.

Žižek, Slavoj. 2001. Did Somebody Say Totalitarianism? London: Verso.

Žižek, Slavoj. 2002. Welcome to the Desert of the Real. London: Verso.

Žižek, Slavoj. 2008 [1989]. The Sublime Object of Ideology. London: Verso.

Žižek, Slavoj. 2012. The Year of Dreaming Dangerously. London: Verso.

\section{Legislative and administrative acts}

Decree 1475/2015. Decree No. 1475 of 14 November 2015 concerning the application of Statute 55-883 of 3 April 1955. Journal officiel de la République française No. 264, 14 November 2015, p. 21297.

Statute 1501/2015. Statute No. 1501 of 20 November 2015 extending the application of the Statute 55-883 of 3 April 1955 on the state of emergency and reinforcing the efficacy of its provisions. Journal officiel de la République française No. 271, 21 November 2015, p. 21665.

Proclamation 9844/2019. Proclamation 9844 of 15 February 2019 Declaring a a National Emergency Concerning the Southern Border of the United States. 84 Federal Register No. 34, 20 February 2019.

\section{Case-law}

Miller 1.R (Miller) v Secretary of State for Exiting the European Union [2017] UKSC 5.

Miller 2. R (Miller) v Prime Minister [2019] UKSC 41. 